\title{
The Early Appearing Bilirubin: Evidence for Two Components *
}

\author{
T. Yamamoto, Joan Skanderbeg, A. Zipursky, and L. G. Israels \\ (From the Departments of Medicine and Pediatrics, University of Manitoba, and the \\ Manitoba Cancer Treatment and Research Foundation, Winnipeg, Canada)
}

The studies of London, West, Shemin, and Rittenberg (1) and of Gray, Neuberger, and Sneath (2) clearly demonstrated that 10 to $20 \%$ of the total stercobilin excreted is derived from a source other than the heme of circulating red cells. This component was identified by the appearance of labeled stercobilin in the stool within a few days of the administration of $\mathrm{N}^{15}$-labeled glycine and was referred to as the "early labeled" pigment. This alternative pathway of bile pigment production was shown to be responsible for at least $40 \%$ of the bile pigment excreted in one case of pernicious anemia and for 30 to $85 \%$ in cases of congenital porphyria (2-4). Subsequent studies showed a similar process to be operative in thalassemia (5). This pathway of bilirubin production has been of such magnitude in some cases as to result in an overproduction type of hyperbilirubinemia disproportionate to that expected on the basis of the observed life span of the circulating red cells. Such cases include a family reported from this laboratory $(6,7)$ as well as case reports by Arias (8), Robinson, Vanier, Desforges, and Schmid (9), and Berendsohn, Lowman, Sundberg, and Watson (10). A similar mechanism may be operative in those cases associated with primary liver disease as reported by Kalk and Wildhert (11) and Siede (12). That this fraction of bile pigment was found to be increased in various disorders of erythropoiesis such as pernicious anemia, congenital porphyria, and thalassemia suggested that it is in some way related to red cell formation. The findings of Gray and Scott (13) that this fraction increases after bleeding gave additional support to this concept. A similar increase, how-

\footnotetext{
* Submitted for publication June 8, 1964 ; accepted September 8, 1964.

Supported by grants from the Medical Research Council of Canada and the National Cancer Institute of Canada.
}

ever, was reported by James and Abbott (14) in patients with erythroid aplasia, and they suggested that this fraction may have arisen in part from a nonerythroid source.

Subsequent studies using glycine-2- $\mathrm{C}^{14}$ and delta-aminolevulinic acid ( $\Delta$-ALA)-4- $\mathrm{C}^{14}$ as bilirubin precursors have shown that this early appearing bilirubin is not a single bilirubin fraction but consists of at least two components (15). Gray and Nicholson (16) have also suggested the possibility of a dual source of this bile pigment. The present report amplifies our earlier communications on the existence of two components of the early labeled bile pigment. The first component is thought to be largely of hepatic origin; the second is associated primarily with erythropoiesis. The labeling patterns in pernicious anemia and shunt hyperbilirubinemia are also described.

\section{Methods}

\section{Subjects}

1) Control (Subjects 1 to 5). Clinical data are given in Table I. In those who had a draining T-tube in the common bile duct, the labeled glycine or $\triangle$-ALA was given on the third postoperative day.

2) Pernicious anemia (Subjects 6 to 9). The diagnostic criteria, pertinent clinical data, and the day of the study on which vitamin $B_{12}$ was injected are given in Table II.

3) Primary shunt hyperbilirubinemia (Subjects 10 and 11). The patients studied belong to a family with hyperbilirubinemia previously reported in detail (Cases I and II) (6). Three members of this family had high indirect-reacting serum bilirubin and high concentrations of urobilinogen in urine and stool with a normal or near normal erythrocyte survival. The bone marrows showed normoblastic hyperplasia. The overproduction type of hyperbilirubinemia, which was not related to the breakdown of circulating erythrocytes, was termed "shunt" hyperbilirubinemia, and studies using glycine-2- $\mathrm{C}^{14}$ in Subject 11 showed the early labeled stercobilin to form over $80 \%$ of the excreted bile pigment (7). It was suggested that the excess bilirubin pro- 
TABLE I

Clinical data of control subjects

\begin{tabular}{|c|c|c|c|c|c|}
\hline & Subject 1 & Subject 2 & Subject 3 & Subject 4 & Subject 5 \\
\hline Diagnosis & Hypertension & Cholelithiasis & Cholelithiasis & Cholelithiasis & Cholelithiasis \\
\hline Sex & Male & Male & Male & Male & Female \\
\hline Age & 82 & 72 & 70 & 38 & 18 \\
\hline Weight, $k g$ & 112 & 54 & 72 & 75 & 60 \\
\hline T-tube & No & Yes & Yes & Yes & Yes \\
\hline Hemoglobin, $g / 100 \mathrm{ml}$ & 15.0 & 13.4 & 15.6 & 15.0 & 13.2 \\
\hline $\begin{array}{l}\text { Bilirubin, } m g / 100 m l \\
\text { Direct }\end{array}$ & 0.2 & 0.5 & 0.2 & 0.8 & 0.5 \\
\hline Indirect & 0.8 & 0.7 & 0.7 & 0.5 & 0.5 \\
\hline
\end{tabular}

duction in these cases had as its source the marrow erythrocytes or their precursors either by cell destruction or the direct synthesis of bilirubin by these cells from heme or heme precursors. Both Subjects 10 and 11 had previously been splenectomized.

Subject 10 (Case I) is now 29 years of age. Her jaundice was first noted at the age of 12 , and it has persisted to the present. In 1955 the serum bilirubin was $8.5 \mathrm{mg}$ per $100 \mathrm{ml}$ of which $7.5 \mathrm{mg}$ per $100 \mathrm{ml}$ was indirect-reacting pigment. The reticulocytes ranged from $4.0 \%$ to $5.1 \%$, and the bone marrow showed marked normoblastic hyperplasia. When a splenectomy was done in October 1955, her spleen weighed $340 \mathrm{~g}$. After splenectomy the total serum bilirubin ranged from $2.4 \mathrm{mg}$ to $5.0 \mathrm{mg}$ per $100 \mathrm{ml}$; the fecal urobilinogen was 500 to $600 \mathrm{mg}$ per 24-hour period. The $\mathrm{Cr}^{51}$ red cell survival $\left(\mathrm{t}_{1}\right)$ was 28 days. At the time of this study her hematocrit was $37 \%$; reticulocytes, $2.0 \%$; direct-reacting serum bilirubin, $0.7 \mathrm{mg}$ per $100 \mathrm{ml}$; indirect, $4.0 \mathrm{mg}$ per $100 \mathrm{ml}$. She received $50 \mu \mathrm{c}$ of glycine-2- $\mathrm{C}^{14}$ intravenously.

Subject 11 (Case II) is now 21 years of age. Jaundice was first noted at puberty, and he has remained icteric since that time. When he was first studied at age 16, the only physical findings were jaundice and a spleen palpable 1 to $2 \mathrm{~cm}$ below the left costal margin. The serum bilirubin, ranging from $4.6 \mathrm{mg}$ to $7.8 \mathrm{mg}$ per 100 $\mathrm{ml}$, was chiefly indirect reacting. The reticulocytes ranged from 2 to $4.6 \%$, and the bone marrow was hypercellular and normoblastic. The $\mathrm{Cr}^{51}$ red cell survival $t_{1}$ was 19 days. The spleen, when removed in 1957, weighed $350 \mathrm{~g}$. After splenectomy the $\mathrm{Cr}^{51}$ red cell survival $t_{\frac{1}{2}}$ was 34 days. The total serum bilirubin ranged from 2.2 to $4.5 \mathrm{mg}$ per $100 \mathrm{ml}$. The 24-hour excretion of urobilinogen in the stool has ranged from $900 \mathrm{mg}$ to $1,200 \mathrm{mg}$. At the time of this study his hematocrit was $39 \%$; reticulocytes, $4.6 \%$; direct serum bilirubin, $0.3 \mathrm{mg}$ per $100 \mathrm{ml}$; indirect, $3.8 \mathrm{mg}$ per $100 \mathrm{ml}$. $\mathrm{He}$ received $50 \mu \mathrm{c}$ of glycine-2- $\mathrm{C}^{14}$ and subsequently 12.5 $\mu \mathrm{c}$ of $\Delta-\mathrm{ALA}-4-\mathrm{C}^{14}$.

\section{Procedures}

In all adult subjects 30 to $40 \mathrm{ml}$ of blood was taken in heparin before and after injection of $50 \mu \mathrm{c}$ of glycine$2-C^{14}$ or $12.5 \mu \mathrm{c}$ of $\Delta$-ALA-4-C $C^{14}$, at intervals as shown in the accompanying figures. The volume of blood taken depended on the plasma bilirubin level and the hematocrit. In those subjects with a draining T-tube, bile collections were obtained before administration of the label, 30 minutes thereafter, and then in 2- to 12-hour block samples as shown. The glycine and $\Delta$-ALA were

TABLE II

Clinical data of subjects with pernicious anemia

\begin{tabular}{|c|c|c|c|c|}
\hline & Subject 6 & Subject 7 & Subject 8 & Subject 9 \\
\hline Sex & Female & Male & Female & Female \\
\hline Age & 80 & 39 & 72 & 82 \\
\hline Weight, $k g$ & 81 & 63 & 52 & 65 \\
\hline Hemoglobin, $\mathrm{g} / 100 \mathrm{ml}$ & 8.2 & 4.2 & 4.5 & 5.0 \\
\hline Reticulocytes, \% & 1.2 & 6.3 & 3.6 & 2.2 \\
\hline Leukocytes, $\mathrm{mm}^{3}$ & 3,800 & 1,500 & 1,500 & 3,300 \\
\hline Bone marrow & Megaloblastic & Megaloblastic & Megaloblastic & Megaloblastic \\
\hline \multicolumn{5}{|l|}{ Bilirubin, $\mathrm{mg} / 100 \mathrm{ml}$} \\
\hline Direct & 0.5 & 0.6 & 0.8 & 0.4 \\
\hline Indirect & 0.5 & 1.9 & 1.0 & 0.6 \\
\hline Day of $B_{12}$ administration & 7 & 8 & 4 & 9 \\
\hline \multicolumn{4}{|l|}{ Maximal response } & \\
\hline Hemoglobin, $\mathrm{g} / 100 \mathrm{ml}$ & 13.8 & 10.2 & 13.4 & 14.8 \\
\hline Tracer & Glycine-2-C $C^{14}$ & Glycine-2-C 14 & Glycine-2-C $\mathrm{C}^{14}$ & $\Delta$ ALA-4-C 14 \\
\hline
\end{tabular}


given intravenously as a single rapid injection in a total volume of 1 to $5 \mathrm{ml}$ of $0.85 \%$ saline.

Bilirubin concentration was determined by the diazo method of Malloy and Evelyn (17).

Bilirubin was precipitated from bile with barium chloride and isolated by the use of the alumina column of Schwartz and Watson (18). The method has previously been described in detail (19). In all graphs the points showing the specific activity of bilirubin isolated from bile represent the end of that block collection period.

Bilirubin was isolated from plasma samples of 10 to $25 \mathrm{ml}$. To this plasma $0.18 \mathrm{vol}$ of saturated ammonium sulfate and 2.5 vol of $95 \%$ ethanol were added and allowed to stand at $4^{\circ} \mathrm{C}$ for 1 hour. The precipitate was spun down, and ethanol and ammonium sulfate again were added to the supernatant to assure complete precipitation. A small quantity of ascorbic acid was added to prevent oxidation and the supernatant taken to dryness under vacuum at $40^{\circ} \mathrm{C}$. The residue was dissolved in chloroform, filtered, and applied to an aluminum oxide (BDH) column $1 \mathrm{~cm}$ in diameter, washed with chloroform, and finally eluted with $1 \%$ acetic acid in chloroform. The eluate was washed once with an equal volume of water and filtered. The bilirubin concentration of the filtrate was determined, and samples were plated for counting.

The bilirubin thus obtained was taken up in top phase and rechromatographed through the kieselguhr column system of Cole and Lathe (20). As the specific activity of the bilirubin was found to remain constant from the stage of elution from the alumina column through its recovery from the kieselguhr system, the initial alumina column preparation was used throughout this study (19). Because of the low yield of bilirubin from the plasma

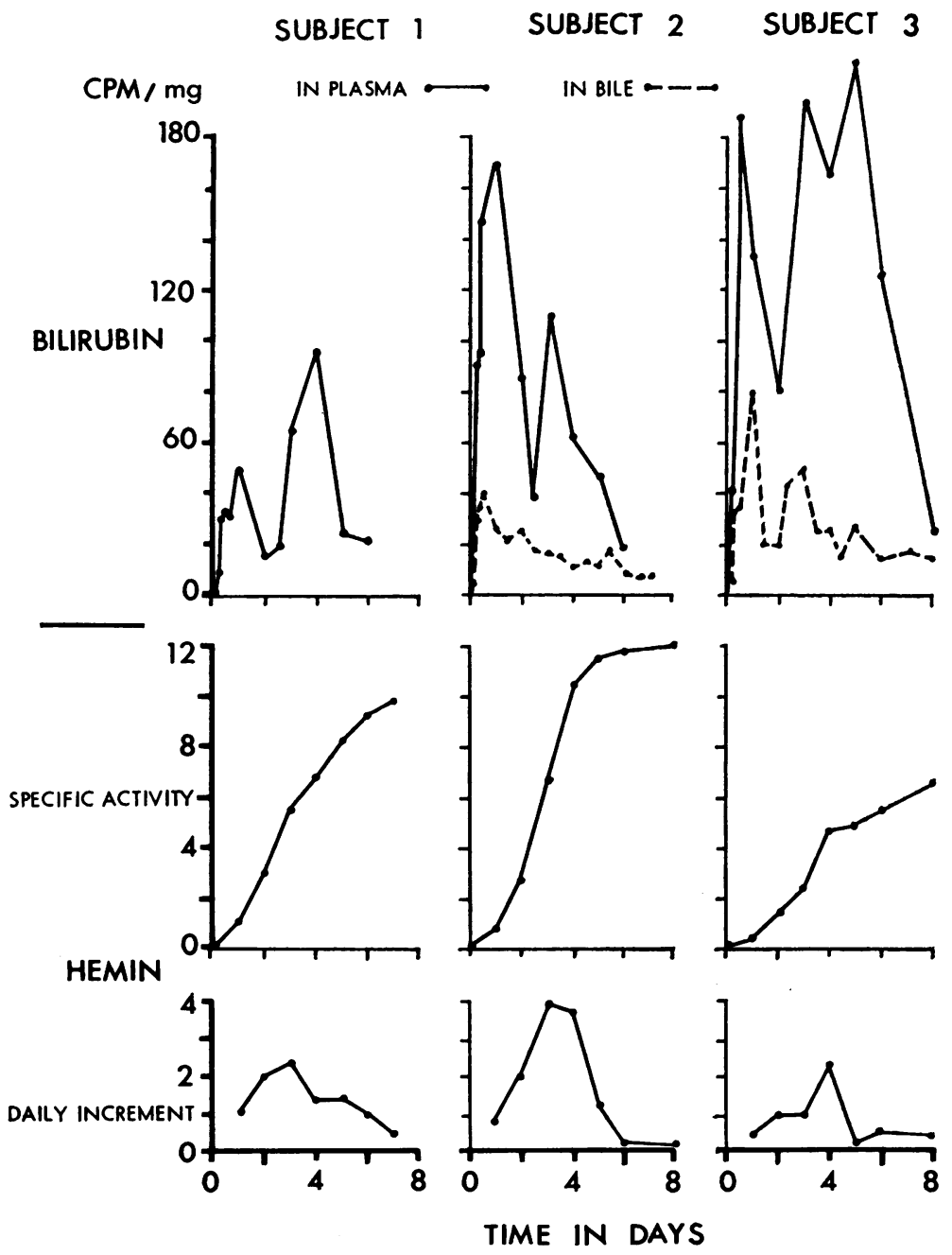

Fig. 1. The SPECIFIC ACtivity OF BILIRUBin ISOLATEd From PLASMa AND BILE, AND OF HEMIN FROM CIRCULATING RED CELLS IN THREE CONTROL SUBJECTS GIVEN $50 \mu c$ OF GLYCINE-2-C14 AT TIME zERO. The daily increment in heme specific activity is also shown. 
in normal subjects, it was not possible to crystallize this bilirubin. To further examine the method, serum was obtained from patients with high levels of indirectreacting bilirubin (two patients with shunt hyperbilirubinemia and one with thalassemia). The bilirubin as eluted from the alumina column was dissolved in chloroform and crystallized from cold methanol by the method of Ostrow, Hammaker, and Schmid (21). The specific activity of the samples before and after crystallization was as follows: before ( $\mathrm{cpm}$ per $\mathrm{mg}$ ) - A, 58; B, 70; C, 56; after (cpm per mg)-A, 66; B, 73; C, 40 .

Hemin was prepared from washed packed red cells as previously described (19). After crystallization weighed samples of hemin were dissolved in $0.1 \mathrm{~N} \mathrm{NaOH}$ and plated at infinite thinness for determination of specific activity.

Globin was prepared by the method of Kassenaar, Morell, and London (22). Five $\mathrm{ml}$ of washed red cells were lysed with water and shaken with $2 \mathrm{ml}$ of toluene to remove the cell stroma. After centrifugation and filtration through Whatman 1 filter paper the hemoglobin solution was added dropwise to 10 vol of $1.2 \%$ hydrochloric acid in acetone. The precipitate was washed with acid acetone, then redissolved in water, precipitated with $14 \%$ trichloroacetic acid, and washed twice with $7 \%$ TCA and once with water. The globin precipitate was redissolved in $1 \mathrm{~N} \mathrm{NaOH}$ and precipitated with $14 \%$ TCA, and the washings were repeated. The globin was finally washed with etheracetone $(1: 1)$ followed by acetone and ether. After air drying, the globin was plated in 100-mg quantities and the radioactivity determined and corrected for self-absorption.

Stercobilin was prepared from total block stool collections and purified to constant specific activity by the method of Watson and associates (23).

$\mathrm{C}^{14}$ activity in bilirubin, stercobilin, hemin, and globin samples was determined with a low background gas flow counter ${ }^{1}$ with an efficiency of $20 \%$.

An estimate of the percentage of injected counts incorporated into circulating heme was calculated from the total number of counts present in circulating heme at peak activity after the administration of the tracer.

${ }^{1}$ Model C115, Nuclear-Chicago Corp., Des Plaines, Ill.
SUBJECT 4

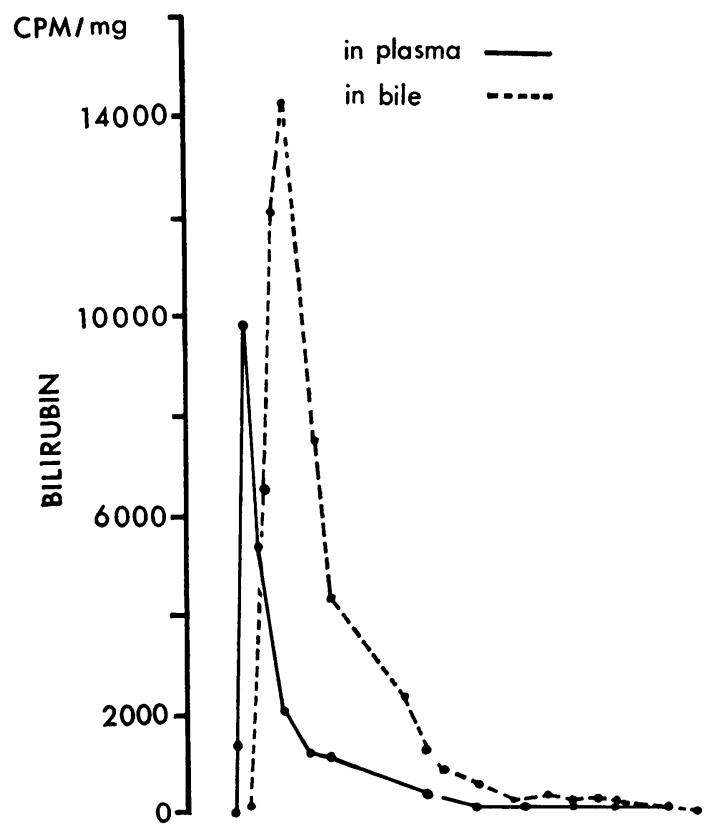

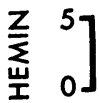

\section{SUBJECT 5}

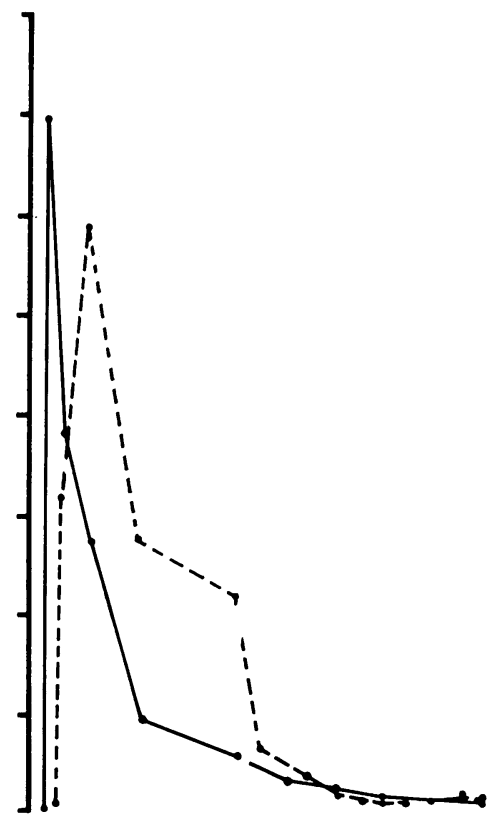

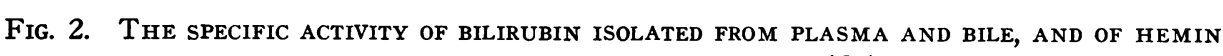
FROM CIRCULATING RED CELLS IN TWO CONTROL SUBJECTS GIVEN $12.5 \mu \mathrm{C}$ of $\Delta$-AMINOLEVULINIC ACID ( $\Delta$-ALA) $-4-C^{14}$ AT TIME ZERO. 
The total circulating heme was based on the hemoglobin content of venous blood and an assumed blood volume of $78 \mathrm{ml}$ per $\mathrm{kg}$.

Heme-globin ratios were calculated according to Kassenaar and associates (22), assuming that a common amino-acid precursor pool exists for both heme and globin and that for every eight molecules of glycine incorporated into heme 41 molecules of glycine are incorporated into globin.

\section{Results}

\section{1) Control}

a) Glycine-2-C'14: Subjects 1,2, and 3. The appearance of labeled bilirubin in the plasma and bile and labeled heme in the circulating red cells is shown in Figure 1. Labeled bilirubin was detected in plasma within 90 minutes of the injection of the glycine-2-C $\mathrm{C}^{14}$, and the specific activity increased until 12 to 24 hours, then fell to a nadir at 48 to 60 hours, and subsequently rose to a second peak on day 3 or 4 . The specific activity then fell away to day 6 at which time a small amount of radioactivity remained in the plasma bilirubin of each subject. The specific activity of the bilirubin recovered from the $T$-tube drainage bile in Subjects 2 and 3 was of much lower specific activity than the plasma bilirubin. Two peaks in bilirubin specific activity in plasma and bile are seen in Subject 3, but only one in the bile in Subject 2.

Labeled heme was present in circulating red cells within 24 hours of the administration of glycine-2-C $\mathrm{C}^{14}$ and began to plateau on days 4 to 6 . The maximal daily increment in the specific activity of labeled heme occurred on days 3 to 4 . The percentage of injected counts appearing in circulating heme in Subjects 1,2, and 3 was $2.65 \%, 2.45 \%$, and $1.62 \%$ of the total injected counts.

b) $\Delta-A L A-4-C^{14}$ : Subjects 4 and 5 . The results obtained in Subjects 4 and 5 given $\Delta$-ALA4-C ${ }^{14}$ are shown in Figure 2. In Subject 4 labeled bilirubin was first detected in the plasma 20 minutes following the injection of labeled $\Delta$-ALA, and peak activity was observed within 90 minutes. In Subject 5 the maximal observed activity was at the time of the first sampling (90 minutes), and the peak may well have occurred before this. The specific activity was much higher than that obtained with glycine-2-C $\mathrm{C}^{\mathbf{1 4}}$, and activity fell sharply to low levels at 24 hours. A secondary rise was not observed. Labeled bilirubin in bile was somewhat slower to appear and reached its peak at 6 hours in both subjects. The activity in the bile exceeded that of the plasma from 6 to 72 hours, following which the activities were of the same order.

The incorporation of the $\mathrm{C}^{14}$ label into heme was minimal, and fewer than $0.5 \mathrm{cpm}$ per $\mathrm{mg}$ was present on day 8. The percentage of injected counts appearing in circulating heme in Subjects 4 and 5 was $0.28 \%$ and $0.12 \%$ of the total injected counts.

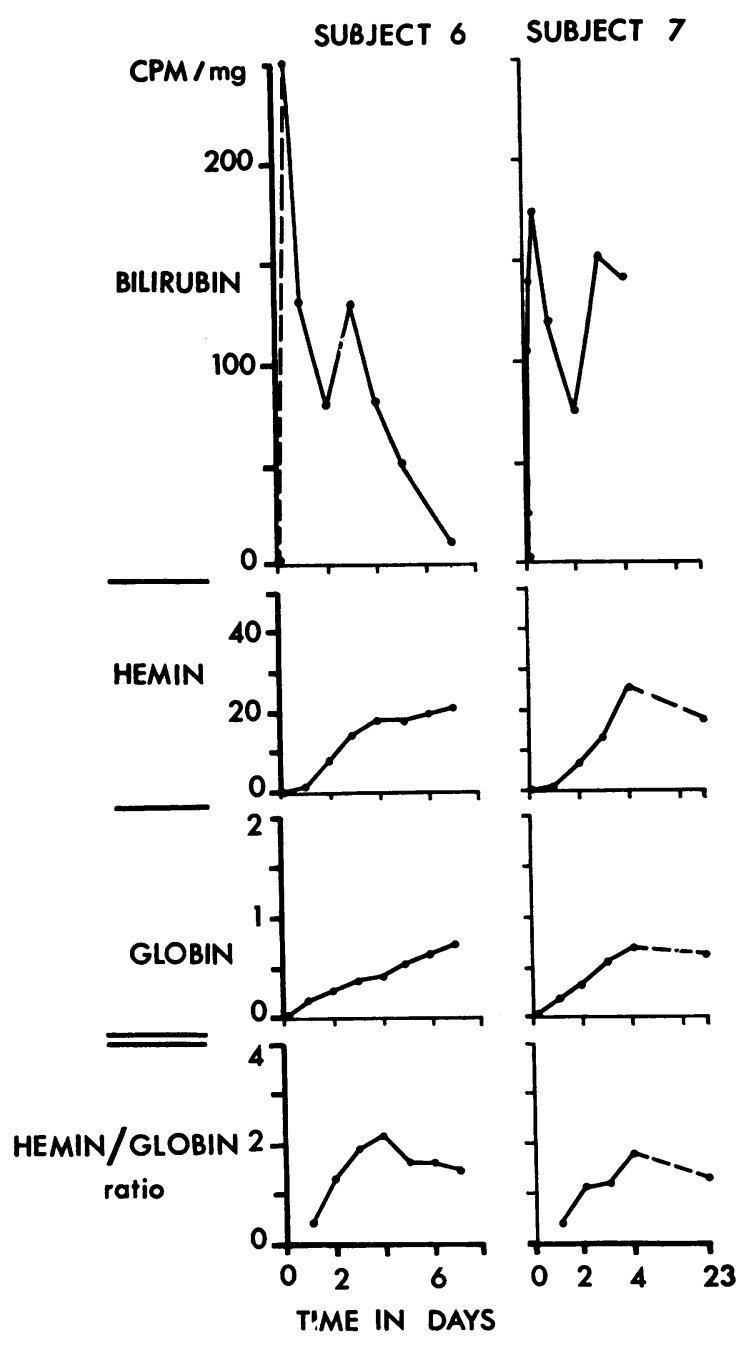

Fig. 3. The SPECific ACtivity of Bilirubin isolated FROM PLASMA, AND OF HEMIN AND GLOBIN ISOLATED FROM THE CIRCULATING RED CELLS IN TWO PATIENTS WiTH PERNICIOUS ANEMIA GIVEN $50 \mu c$ OF GLYCINE-2-C ${ }^{14}$ AT ZERO TIME. The heme-globin ratio is also shown. 


\section{2) Pernicious anemia}

a) Glycine-2-C ${ }^{14}$ : (Subjects 6 and 7). The appearance of the $\mathrm{C}^{14}$ in plasma bilirubin, heme, and globin is shown in Figure 3. Two peaks of bilirubin activity are present in Subjects 6 and 7 with an initial peak at 6 hours and a second peak on day 3. The incorporation of $\mathrm{C}^{14}$ into heme reached peak activity on day 4 in both subjects. The hemeglobin ratio rose from 0.3 on day 1 to peak on day 4 and subsequently fell to 1.6 in Subject 6 and 1.3 in Subject 7. The number of injected counts emerging as circulating heme in Subjects 6 and 7 was $2.33 \%$ and $2.17 \%$.

b) Glycine-2-C $C^{14}$ : (Subject 8). In this patient stercobilin was isolated from block collections of stool. The appearance of the $\mathrm{C}^{\mathbf{1 4}}$ label in serum bilirubin, stercobilin, and hemin is shown in Figure 4. The first sample of serum bilirubin was obtained at 48 hours at which time the specific activity was $750 \mathrm{cpm}$ per $\mathrm{mg}$. In view of the findings in Subjects 6 and 7, the bilirubin was probably labeled much in advance of this, and the first peak was missed in this subject because of the late sampling. It is of great interest that the stool collected during the 48 hours following the glycine-2- $\mathrm{C}^{14}$ showed no radioactivity in the isolated stercobilin. The stercobilin peak of $200 \mathrm{cpm}$ per $\mathrm{mg}$ was in the day 5 to 6 collection and followed by 24 to 36 hours the plasma peak of $1,150 \mathrm{cpm}$ per $\mathrm{mg}$ observed on day 4 . The incorporation of $\mathrm{C}^{14}$ into circulating heme reached peak activity by day 6 , and $1.5 \%$ of the injected counts emerged as circulating red cell heme.

c) $\Delta-A L A-4-C^{14}:($ Subject 9$)$. Subject 9 was given $12.5 \mu \mathrm{c}$ of $\Delta$-ALA-4-C ${ }^{14}$ intravenously. The maximal specific activity of the plasma bilirubin was observed at 12 hours at the time of the initial sample, and in view of the findings in other subjects given this tracer (Subjects 4, 5, and 11), the peak activity probably occurred before this sampling. The specific activity then decreased to low levels by day 3. Little activity appeared in heme with less than $0.5 \mathrm{cpm}$ per $\mathrm{mg}$ in the circulating heme by day 6 (Figure 5 ).

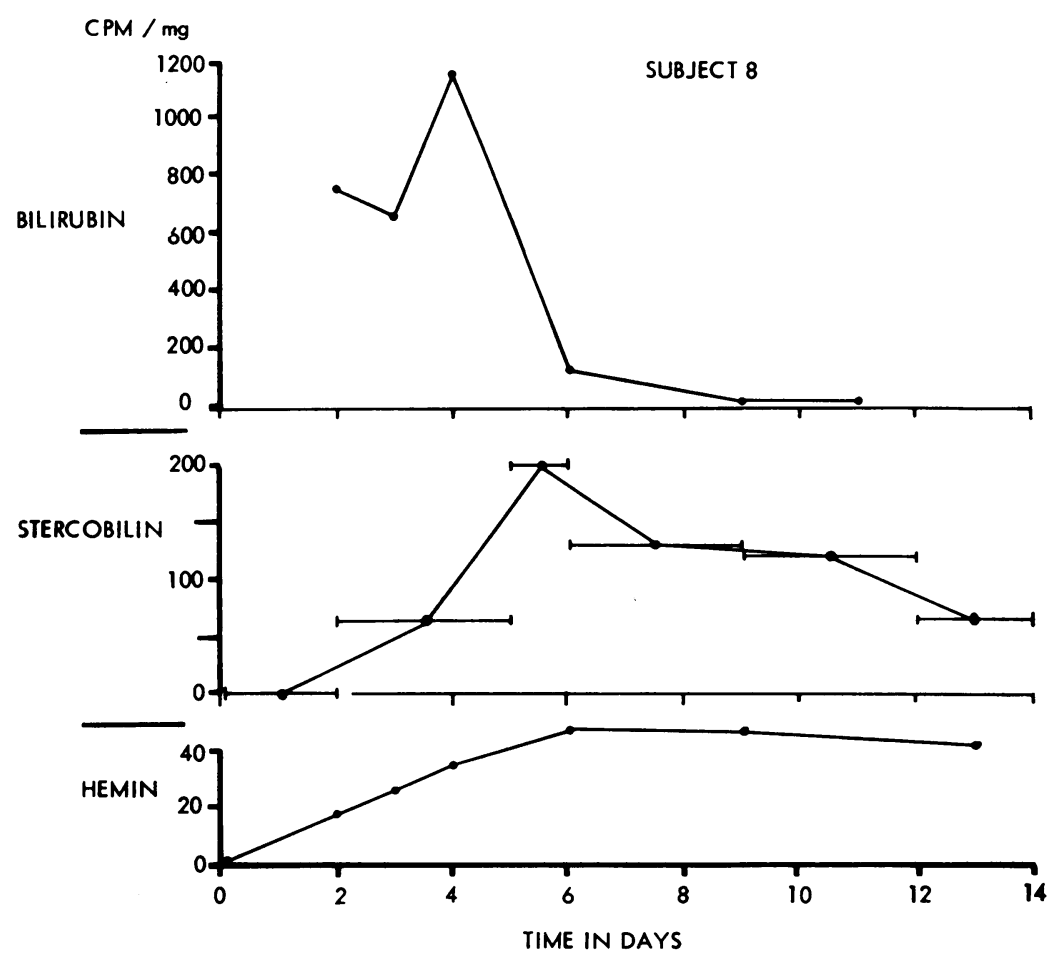

Fig. 4. The SPECIFIC ACTIVIty OF BILIRUBin ISOlated FROM PLASMA, HEMiN FROM CIRCULATING RED CELLS, AND STERCOBILIN FROM BLOCK STOOL COLLECTIONS in a patient with pernicious anemia given $50 \mu \mathrm{C}$ of GLyCine-2-C ${ }^{14}$ at time ZERO. 
3) Primary shunt hyperbilirubinemia: Subjects 10 and 11

The results in these two siblings given $50 \mu \mathrm{c}$ of glycine-2- $\mathrm{C}^{14}$ are shown in Figure 6. The label was found to be incorporated into the circulating bilirubin within 6 to 12 hours and then continued to increase in activity, reaching a maximum at day 3 in Subject 11 and day 4 in Subject 10. The incorporation of $\mathrm{C}^{14}$ into circulating heme was evident at 48 hours and increased to day 7 with the maximal daily increment on days 3 and 4 . The heme-globin ratios in each subject rose from 0.5 and 0.98 on day 1 to a maximum of 1.75 and 2.0 on days 3 to 4 and then fell to 1.2 on day 7 . The percentage of injected counts incorporated into circulating heme was $1.51 \%$ in Subject 10 and $1.8 \%$ in Subject 11 .

Subject 11 was subsequently given $12.5 \mu \mathrm{c}$ of $\Delta$-ALA-4-C ${ }^{14}$. The incorporation into bilirubin and heme is shown in Figure 5 and closely resembles the pattern in the control subjects.

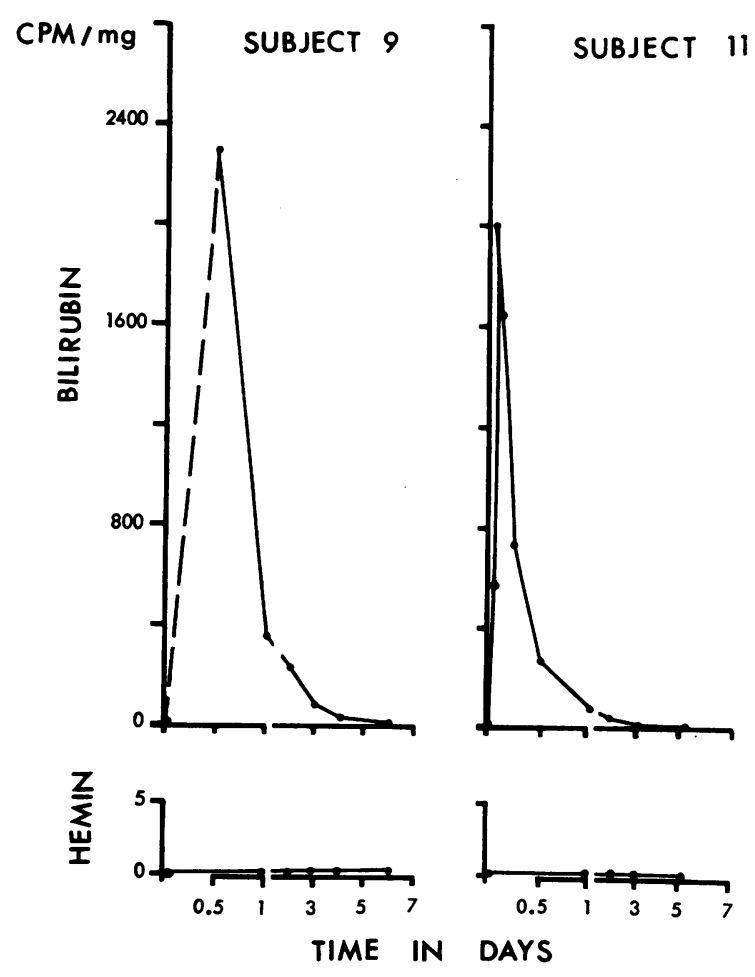

Fig. 5. THE SPECIFIC ACtivity OF BILIRUBin isolated FROM PLASMA, AND OF HEMIN FROM CIRCULATING RED CELLS IN TWO SUBJECTS GIVEN $12.5 \mu \mathrm{C}$ OF $\Delta$-ALA-4-C ${ }^{14}$ AT TIME ZERO. Subject 9 is a patient with pernicious anemia; Subject 11 has shunt hyperbilirubinemia.

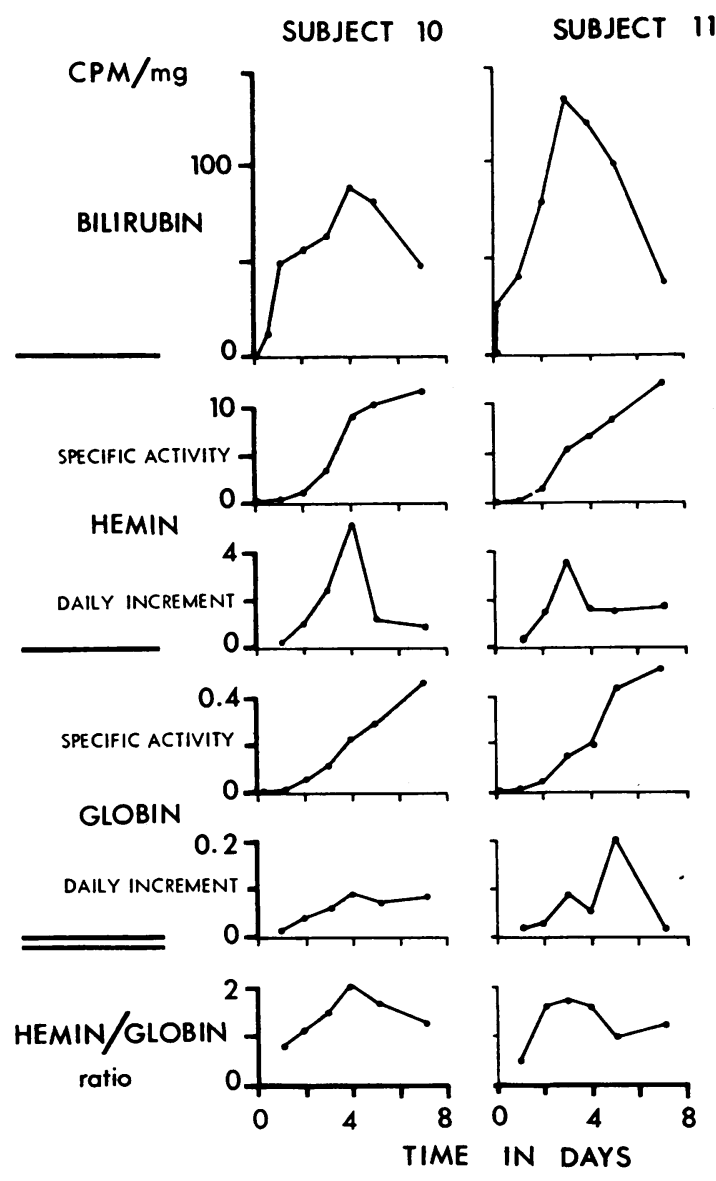

Fig. 6. The SPECIFIC ACTIVITy OF BILIRUBiN ISOLATED FROM PLASMA, AND OF HEMIN AND GLOBIN FROM THE CIRCULATING RED CELLS OF TWO PATIENTS WITH SHUNT HYPERBILIRUBINEMIA. The daily increment in the specific activity of heme and globin as well as the heme-globin ratio is also shown.

\section{Discussion}

After the administration of labeled glycine, early labeled bile pigment has been demonstrated in stercobilin in stool and bilirubin from bile fistulae in animals and man. In the present study we have examined the labeling pattern of this bilirubin in the plasma immediately after the administration of glycine-2-C ${ }^{14}$ and $\Delta$-ALA-4-C ${ }^{14}$ to humans. The control subjects given glycine-2- $\mathrm{C}^{14}$ exhibited two components of labeled bilirubin in their plasma. The first was detectable at $90 \mathrm{~min}$ utes, and the activity increased to reach a peak at 12 to 24 hours. The second component reached maximal activity 3 to 5 days after the administration of the glycine. This second phase probably 
began on day 1 , the initial part of its production being overlapped by the first component.

The second peak corresponded in time to the maximal increment of radioactivity in red cell heme, a time when the red cells that had incorporated the label 3 to 4 days previously were emerging from the marrow. The observation of Bessis, Breton-Gorius, and Thiery (24) that some hemoglobin accompanies the nucleus of the cell as it is extruded from the erythroblast led them to suggest this to be the source of the early labeled stercobilin, and it may indeed represent an important source of this second component. This mechanism would be consistent with the coincidence of the second peak with the release of maximally labeled red cells from the marrow. In bile fistula dogs given glycine-2- $\mathrm{C}^{14}$ the excretion of labeled bilirubin following the first 12- to 24-hour peak is markedly reduced following total body radiation with resultant marrow aplasia (19). Thus this second component in bile, which is analogous to the second plasma peak, falls along with a decrease in the synthesis of circulating red cell heme. This association of a single early component and poor incorporation of the label into red cell heme is also seen when $\Delta$-ALA is the precursor substance. In two controls receiving $\Delta$-ALA-4-C ${ }^{14}, 0.28 \%$ and $0.12 \%$ of the injected counts appeared in circulating heme. This is of the same order as that reported by Berlin, Neuberger, and Scott $(0.24 \%)$ (25) and compares with 1.68 to $2.65 \%$ for glycine (Table III). The absence of a second peak in the subjects receiving $\Delta$-ALA who incorporated little la-

TABLE III

Per cent of total injected counts incorporated into circulating heme

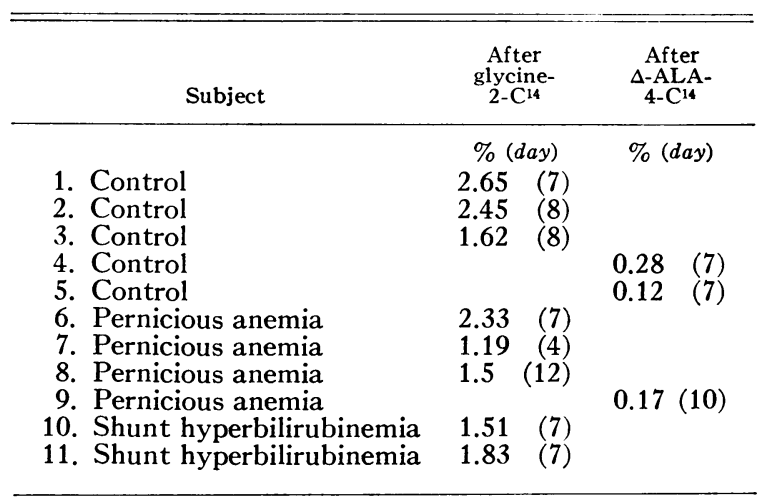

bel into circulating red cells also is in keeping with the relationship of the second component to the synthesis of red cell heme.

The site of origin of the first component is less well defined, but it would seem to be at least in part independent of the synthesis of red cell heme. In the control subjects given glycine-2- $\mathrm{C}^{14}$ the first labeled bilirubin was detectable at 90 minutes, and the activity increased to a peak at 12 to 24 hours. In studies on bile fistula dogs this first component persisted following radiation-induced marrow aplasia, suggesting that it was independent of erythropoiesis. As the two main sites of heme and porphyrin synthesis are the erythropoietic cells of the marrow and the hepatic parenchymal cells, this suggested the liver as a possible site of origin of the first peak. Further, in bile fistula dogs with Sedormid-induced porphyria the labeling of the bilirubin by glycine-2-C ${ }^{14}$ was accelerated to approximate in time the rapid labeling following $\Delta$-ALA-4-C ${ }^{14}$ (26). As Sedormid porphyria is primarily a hepatic porphyria with no demonstrable changes in bone marrow (27), this again suggests the first component to be at least in part of hepatic origin. The role of the liver in the formation of the early labeled bilirubin was put forward by Rimington (28), and evidence for the hepatic origin of some of the bile pigments was presented by Gray and co-workers (29).

The labeling pattern following $\Delta$-ALA-4-C ${ }^{14}$ showed only a sharp initial peak that was more rapid than glycine, with labeled bilirubin detectable at 20 minutes and reaching higher peak activity within 90 minutes. This difference in time and degree of incorporation of these precursors into bilirubin may relate to cell permeability, differences in pool size, and to the rapid clearance of $\Delta$-ALA. That $\Delta$-ALA is a better precursor of the early bilirubin than is glycine has been shown in normal bile fistula dogs where $7 \%$ to $11 \%$ of the injected radioactivity of $\Delta$-ALA-4-C ${ }^{14}$ is incorporated into the early labeled bilirubin as compared with $0.07 \%$ to $0.15 \%$ for glycine- $2-C^{14}$ (30).

This difference in the labeling pattern of glycine and $\Delta$-ALA is also reflected in their relative labeling of the bilirubin in the plasma and bile. In Subjects 4 and 5 given $\Delta$-ALA-4-C ${ }^{14}$ the labeling patterns in plasma and bile are very similar; however, peak specific activity in the bilirubin of the bile followed that in the plasma by 4 to 6 
hours. At this time the plasma activity had fallen away, and the specific activity of the bilirubin in the bile then exceeded that in the plasma over the next 24 hours. Some of the lag in the rise of $\mathrm{C}^{14}$ activity in the bilirubin in the bile as compared with that in the plasma may be due in part to the unlabeled bilirubin occupying the bile ducts and $\mathrm{T}$-tube at the time of injection. If the liver is a primary site of bilirubin synthesis from infused $\Delta$-ALA, then bilirubin enters the circulating plasma at a rapid rate and is also rapidly cleared in the bile. The continuing high activity in the bile for a period of 6 to 12 hours after plasma activity has fallen away suggests hepatic synthesis with direct excretion into the bile.

In contrast to the findings with $\triangle$-ALA the specific activity of the bilirubin obtained from the bile was much less than that of the plasma in Subjects 2 and 3 given glycine-2-C ${ }^{14}$. The reason for this plasma-bile difference is not known; the possibilities include the following. 1) There is a $\mathrm{C}^{14}$-labeled contaminant arising from glycine but not from $\Delta$-ALA that is associated with the isolated plasma bilirubin. If this is so, it is firmly fixed to the plasma bilirubin, as the specific activity remains constant through two column systems and crystallization. 2) The bilirubin in the bile is diluted by unlabeled bilirubin arising in the spleen and passing directly to the liver via the splenic vein. The bilirubin content of splenic vein blood is probably greater than that of peripheral blood, and this can be demonstrated in patients with congenital spherocytosis (31). 3) A part of the plasma bilirubin formed from glycine is excreted as a bile pigment other than bilirubin. This possibility is suggested by the discrepancy between the times of labeling of plasma bilirubin and stool stercobilin. Maximal labeling in the stool does not take place for 3 to 5 days with little or no labeling in the first 24 to 48 hours. This is also apparent in other studies $(7,29)$. Allowing for gut transit time, the rapid appearance of the label in plasma and bile bilirubin is not mirrored and suggests the possibility that part of the earliest labeled plasma bilirubin is excreted as a pigment other than stercobilin. Early labeling of mesobilifuscin in the stool was demonstrated by Gilbertsen, Lowry, Hawkinson, and Watson (32), and this labeling preceded that of stercobilin. The possibility that mesobilifuscin arises in whole or in part from this bilirubin fraction must be considered.

The patients with pernicious anemia given glycine-2- $C^{14}$ and $\Delta$-ALA-4-C $C^{14}$ show plasma labeling patterns similar to the control subjects. The specific activity is equivalent to or higher than that in the control subjects, which in the presence of a higher serum bilirubin indicates that the formation of early labeled bile pigment is greater than in the normal subject. This is in agreement with the original observations of London and West (3). That the first peak is equivalent to or exceeds the second in specific activity is of particular interest, suggesting that the excess bilirubin arising in pernicious anemia is not solely of erythropoietic origin (ineffective erythropoiesis) but may also in part be due to the increased turnover of hepatic heme.

In an attempt to gain further information on the mode of origin of that early labeled bilirubin that arises in relation to erythropoiesis, we determined the heme-globin ratios in those patients with pernicious anemia and shunt hyperbilirubinemia. We had previously suggested that if the hemoglobin forming cells in the marrow were the primary site of formation of the early appearing bilirubin, then the heme-globin ratio might be of value in determining if it were arising from the loss of preformed hemoglobin or from a direct metabolic shunt from heme precursors. If loss of preformed hemoglobin due to cell loss late in maturation (ineffective erythropoiesis) were taking place, this would result in a decrease in the total amount of radioactivity emerging from the marrow in both heme and globin, but the relative amounts of each and thus the heme-globin ratio would remain unchanged. If, however, there is a direct metabolic shunt from heme precursors to bilirubin, then following a single pulse of glycine$2-\mathrm{C}^{14}$ the loss of $\mathrm{C}^{14}$-labeled heme or heme precursors from the heme pool would lower the hemeglobin ratio. Were the latter the case, an increase in the production of early labeled bile pigment and a low heme-globin ratio would be expected to occur together. Low heme-globin ratios have been recorded along with increased production of early labeled stercobilin in thalassemia (5). The hemeglobin ratios in the patients with pernicious anemia 5 days or more after the administration of the glycine-2-C ${ }^{14}$ were greater than 1 . Although our 
values are higher than those obtained by Nathan and Gardner in pernicious anemia (33), their ratios in pernicious anemia were similar to those of their normal subjects $(33,34)$. It is unlikely, therefore, that much of the second bilirubin fraction arises from the direct conversion of erythropoietic heme or its precursors within the marrow.

Subjects 10 and 11 with shunt hyperbilirubinemia given glycine-2- $\mathrm{C}^{14}$ showed a different pattern of early bilirubin labeling from that of the controls and the patients with pernicious anemia. The appearance of the label in circulating bilirubin was noted at 8 to 12 hours with leveling off of activity and then a further increase to day 4 followed by falling plasma bilirubin radioactivity. Two peaks were not seen but rather an initial rapid phase followed by a gradual increase to day 4. This pattern is consistent with predominance of the second peak that blends with and obscures the area usually seen as a trough between the two components, and this suggests that in these patients the early labeled bilirubin has its origin primarily within the marrow. The normoblastic hyperplasia of the marrow in these patients is in keeping with the present findings. In the initial report on these cases it was suggested that the over production of bile pigment has as its source the marrow erythrocytes or their precursors and arose either by the destruction of preformed hemoglobin or the direct synthesis of bilirubin from heme or its precursors. The heme-globin ratio in excess of 1 is against a direct pathway from heme precursors, and this bilirubin probably is derived from hemoglobin released by intact or disintegrating red cells or their precursors within the marrow. The intrinsic defect of these cells is not defined but is associated with either normal or a minor shortening of red cell life span in the peripheral blood.

It has been demonstrated that the early appearing bile pigment probably originates from at least two sources and that there is a relative difference in their contribution in the two clinical states described. The increase in early labeled bilirubin in association with disturbances in erythropoiesis, porphyrin metabolism, or liver disease suggests that the mechanism or site of increased production may vary and must be individually defined for each group of diseases.

\section{Summary}

1) The rapid phase of bilirubin labeling in plasma and bile was studied in human subjects following the intravenous administration of glycine-2- $\mathrm{C}^{14}$ and delta-aminolevulinic acid ( $\Delta$-ALA)4-C ${ }^{14}$.

2) After glycine-2-C $\mathrm{C}^{14}$ the isolated plasma bilirubin exhibited two peaks, the first at 12 to 24 hours and a second between days 3 and 5 . The second peak coincided in time with the maximal increment in the appearance of circulating red cell heme.

3) When $\Delta$-ALA-4-C ${ }^{14}$ was the precursor substance, one peak of bilirubin activity was found in plasma at 1.5 to 6 hours. There was no second peak, and labeling of red cell heme was minimal.

4) It is suggested that the so-called early labeled bile pigment is made up of at least two components, the first being in part independent and the second dependent on red cell heme synthesis. It is proposed that the initial peak has its origin largely in the liver, the second primarily in the marrow.

5) Labeling patterns in pernicious anemia and primary shunt hyperbilirubinemia are described. In the latter the labeling pattern suggests the marrow to be the main site of bilirubin production.

\section{References}

1. London, I. M., R. West, D. Shemin, and D. Rittenberg. On the origin of bile pigment in normal man. J. biol. Chem. 1950, 184, 351.

2. Gray, C. H., A. Neuberger, and P. H. A. Sneath. Studies in congenital porphyria. Incorporation of ${ }^{15} \mathrm{~N}$ in the stercobilin in the normal and in the porphyric. Biochem. J. 1950, 47, 87.

3. London, I. M., and R. West. The formation of bile pigment in pernicious anemia. J. biol. Chem. 1950, $184,359$.

4. London, I. M., R. West, D. Shemin, and D. Rittenberg. Porphyrin formation and hemoglobin metabolism in congenital porphyria. J. biol. Chem. 1950, 184, 365.

5. Grinstein, M., R. M. Bannerman, J. D. Vavra, and C. V. Moore. Hemoglobin metabolism in thalassemia. In vivo studies. Amer. J. Med. 1960, 29, 18.

6. Israels, L. G., J. H. Suderman, and S. E. Ritzmann. Hyperbilirubinemia due to an alternate path of bilirubin production. Amer. J. Med. 1959, 27, 693.

7. Israels, L. G., and A. Zipursky. Primary shunt hyperbilirubinaemia. Nature (Lond.) 1962, 193, 73. 
8. Arias, I. M. Chronic unconjugated hyperbilirubinemia $(\mathrm{CUH})$ with increased production of bile pigment not derived from the hemoglobin of mature, circulating erythrocytes. J. clin. Invest. 1962, 41, 1341.

9. Robinson, S., T. Vanier, J. F. Desforges, and R. Schmid. Jaundice in thalassemia minor. A consequence of "ineffective erythropoiesis." New Engl. J. Med. 1962, 267, 523.

10. Berendsohn, S., J. Lowman, D. Sundberg, and C. J. Watson. Idiopathic dyserythropoietic jaundice. Blood 1964, 24, 1.

11. Kalk, H., and E. Wildhert. Die posthepatitische Hyperbilirubinaemie. Z. klin. Med. 1955, 153, 354.

12. Siede, W. Die nicht haemolytische Hyperbilirubinaemie ohne direkte van den Bergh Reaktion. Dtsch. med. Wschr. 1957, 82, 504.

13. Gray, C. H., and J. J. Scott. The effect of haemorrhage on the incorporation of $\left(\alpha-{ }^{14} \mathrm{C}\right)$ glycine into stercobilin. Biochem. J. 1959, 71, 38.

14. James, G. W., III, and L. D. Abbott, Jr. Stercobilin $\mathrm{N}^{25}$ excretion in refractory anemia. Trans. Amer. clin. climat. Ass. 1961, 73, 110.

15. Israels, L. G., T. Yamamoto, J. Skanderbeg, and A. Zipursky. Shunt bilirubin: evidence for two components. Science 1963, 139, 1054.

16. Gray, C. H., and D. C. Nicholson. Pathways of bile pigment metabolism. Ann. N. Y. Acad. Sci. 1963, 111, 281.

17. Malloy, H. T., and K. A. Evelyn. The determination of bilirubin with the photoelectric colorimeter. J. biol. Chem. 1937, 119, 481.

18. Schwartz, S., and C. J. Watson. Isolation of a dextrorotatary urobilin from human fistula bile. Proc. Soc. exp. Biol. (N. Y.) 1942, 49, 641.

19. Israels, L. G., J. Skanderbeg, H. Guyda, W. Zingg, and A. Zipursky. A study of the early-labelled fraction of bile pigment: the effect of altering erythropoiesis on the incorporation of $\left[2{ }^{14} \mathrm{C}\right] \mathrm{gly}-$ cine into haem and bilirubin. Brit. J. Haemat. 1963, 9, 50.

20. Cole, P. G., and G. H. Lathe. The separation of serum pigments giving the direct and indirect Van den Bergh reaction. J. clin. Path. 1953, 6, 99.

21. Ostrow, J. D., L. Hammaker, and R. Schmid. The preparation of crystalline bilirubin- $\mathrm{C}^{\mathbf{1 4}}$. J. clin. Invest. 1961, 40, 1442.

22. Kassenaar, A., H. Morell, and I. M. London. The incorporation of glycine into globin and the syn- thesis of heme in vitro in duck erythrocytes. J. biol. Chem. 1957, 229, 423.

23. Watson, C. J., P. T. Lowry, V. E. Sborov, W. H. Hollingshead, S. Kohan, and H. O. Matte. A simple method of isolation of crystalline stercobilin or urobilin from feces. J. biol. Chem. 1953, 200, 697.

24. Bessis, M., J. Breton-Gorius, and J-P. Thiery. Rôle possible de l'hemoglobine accompagnant le noyau des érythroblastes dans l'origine de la stercobiline éliminée précocement. C. R. Acad. Sci. (Paris) 1961, 252, 2300.

25. Berlin, N. I., A. Neuberger, and J. J. Scott. The metabolism of $\delta$-aminolaevulic acid. 2. Normal pathways, studies with the aid of ${ }^{14} \mathrm{C}$. Biochem. J. 1956, 64, 90.

26. Israels, L. G., T. Yamamoto, J. Skanderbeg, and A. Zipursky. Alternate pathways of bilirubin production. Proceedings of the 9th Congress of the European Society of Hematology, Lisbon, 1963. Basel, Karger, 1964, p. 891.

27. Schmid, R., and S. Schwartz. Experimental porphyria, III. Hepatic type produced by Sedormid. Proc. Soc. exp. Biol. (N. Y.) 1952, 81, 685.

28. Rimington, C. Biochemical aspects of porphyrin disorders in Biochemical Aspects of Neurological Disorders, J. Cumings and M. Kremer, Eds. Oxford, Blackwell, 1959, p. 63.

29. Gray, C. H., A. Kulczycka, D. C. Nicholson, I. A. Magnus, and C. Rimington. Isotope studies on a case of erythropoietic protoporphyria. Clin. Sci. 1964, 26, 7.

30. Israels, L. G., and J. Skanderbeg. Unpublished data.

31. Dacie, J. V. The Hemolytic Anemias, Part I. London, J. \& A. Churchill, 1960, p. 134.

32. Gilbertsen, A. S., P. T. Lowry, V. Hawkinson, and C. J. Watson. Studies of the dipyrrylmethene ("fuscin") pigments. I. The anabolic significance of the fecal mesobilifuscin. J. clin. Invest. 1959, 38, 1166.

33. Nathan, D. G., and F. H. Gardner. Erythroid cell maturation and hemoglobin synthesis in megaloblastic anemia. J. clin. Invest. 1962, 41, 1086.

34. Nathan, D. G., S. Piomelli, and F. H. Gardner. The synthesis of heme and globin in the maturing human erythroid cell. J. clin. Invest. 1961, 40, 940. 